\title{
Some Thoughts about Building a Mentor's Workshop with Craftsman's Spirit

\author{
Yunfeng Huang ${ }^{1}$ and Baosheng Guo ${ }^{2 *}$
}

${ }^{1}$ Beihua University the Foreign Language Department's Student Work Office, Jilin Jilin 132013

${ }^{2}$ Beihua University student work place, Jilin Jilin 132013

982489261@qq.com, 492171239@qq.com

*The Corresponding Author

Keywords: Craftsman Spirit; Counsellor; Studio; Thinking

\begin{abstract}
This article aims to introduce the meaning and connotation of "Craftsman's Spirit", which analyzes the connotation of the counsellor's "Craftsman's Spirit" and the method of combining the "Craftsman's Spirit" with the establishment of counselor studio. It radically makes the counselor studio into the craftsman's shop, which requires integrate the "Craftsman Spirit". It should associate the innovation with the preciseness to renew the ways of working and the methods of educating students, which will prosper the campus' culture.
\end{abstract}

\section{The Meaning of Craftsman's Spirit}

"Craftsman 's spirit" refers to the craftsmen who pursuit perfection of their products and more excellent quality. On the one hand, it's about the Craftsman (Here is the counselor, hereinafter refers to as craftsman) of the professional spirit and professional ethics, on the other hand, it's the craftsmen spiritual guidance. The craftsmen who have Craftsman's spirit are convinced of this way which all focuson perfecting their foundry products to perfection. Keep the craft that you are following to the fullest. But craftsmen of Craftsman's spirit are not satisfied with this. They insist on the idea that the details determine success. Besides, they insist on the principlethat they should make a magnificent structure (Grand Architecture), and take the meticulous spirit to the extreme. [1]

\section{The Connotation of Craftsman's Spirit}

First of all, what we are confronted with is the Craftsman's repetitive working place and working hours, curing the day-to-day work. There are more requirements for craftsmen: the Craftsman 's meticulous spirit and the pursuit of the perfect professional attitudes.

Craftsman's spirit is one of the spirit of our country with good cultural tradition. It is not only a spirit, but also the craftsman's demand for his work and life philosophy.

In short, craftsman's spirit is whether in the charge of people or in the case of unattended, craftsmen are able to fulfill the high-standard and strict products with the spirit to pursuit a higher level.

\section{How to Introduce the "Spirit of Craftsman" into the Construction of the Counsellor Studio}

To introduce the "spirit" in the guidance for the construction of the studio, the school must pass the Craftsman's spirit to the freshmen as soon as the students get into the school, which will cultivate them to meet the needs of modern industry "Builders" and make them form the high-standard requirements for learning and life principle. Let every student foster the awe and respect attitude to their career. 
As a counselor, how to apply the spirit of pursuing perfection to their own education, how to get the spirit of them into the daily management of student work, and how to improve yourself in daily work of the spirit and professional quality, which are very serious problems.

The spirit of craftsman also has a high value for guidance counselor's work. Because of this, we can discuss how to introduce the spirit of craftsman into the construction of the tutoring studio.

First, Introduce "the Spirit of the Craftsman" Into the Construction of the Tutoring Studio to Maintain the Ordinary, to Guard Against the Arrogance, and Change the Tutoring Studio Into the "Workshop" of the Craftsmen.

First of all, to be a qualified craftsman. Such a craftsman should be meticulous in his work, and they must pay very closed attention to the materials what they need, keep an eye on the progress of things, and be vigilant constantly. No matter who he is, only the person who can stand loneliness will they become extraordinary. However, being not ordinary is the biggest ordinary. The Craftsman's spirit can only be turned into an intrinsic brand of the Craftsman's spirit, which is truly a great faith.

Even though the world is full of chaos, the workman is doing his research with his heart and soul. [2] Even though there are trials and tribulations in front of him, he will go ahead without hesitation. With the big blundering in today's education background, it is imperative for the counselors to achieve their work, and be down-to-earth to stick to one side pure land, without chasing fame and wealth. Develop the spirit of no distractions. Therefore, he can truly become a person dedicated to research, and a qualified and excellent craftsmen. [3]

In the Analects of Confucius, it is said that those who know best are not so good as those who are better than those who are better. Interest is always the best motivator.

Although the work of the craftsmen is common and ordinary, they have the lofty belief of uncommon, which is the same as the counselor's daily work. However, the counselor is unable to give up the pursuit of greatness because of the ordinary and boring work.

The responsibility of a counselor is to focus on learning and improving his theoretical and practical abilities. If the counselor wants to be perfect in all aspects, he not only needs to be a diligent and hard-working person, but also needs to learn to adapt to different levels of students and learn more flexible to be in different circumstances. Because what the counselor is facing is the new era college students whose thinking is more fashion and trendy. The counselor must timely understand the unique spiritual world of the contemporary college students, and attach more importance to students' own experience, which can make the counselor's work become more vividly and appropriately.

Secondly, the Spirit of Craftsman Should Be Introduced Into the Construction of the Tutoring Studio.

Besides, the innovation and preciseness should be combined. The expression "Exercise one's inventive mind" was invented in ancient times, which we use to describe a special technology innovation's builders [4].Innovation is not only the most important thing in other fields, the spirit of which is also a kind of important performance of the spirit of craftsman. The era is in constant progress and the society is changeable, which requires the counselor to use a variety of different methods to solve different problems. But the fundamental skill is that the counselor should accumulate experience and conclude the solutions in the process of solving these problems, then try to be innovative to find out the best work methods to solve the problem. This is of great significance to the development of education. [5]

The innovative spirit required by the counselor includes essentially two points:

The first point is the innovation spirit of the counselor in managing and guiding students to learn progressive ideas.

The students' thinking is very active, the span of which is very large. The counselor must be adaptable to the development of times to learn the students' spiritual world and grasp their ideological change to fully meet student's actual needs, fundamentally grasp management students, the main points of the innovation management method and direct method.

The management of students is not only for management purposes, but also combines student 
management work with students work together, and associate the student's academic achievement with their life planning organically linked together in the future. [6]

The second point is about hardware innovation. When a new media technology appeared in the eyes of the public, it would immediately become an office use for all major people in the society. As long as we are good at using new media technology, giving full play to the function of the new media technology and expanding the role of new media development. The counselor can finish the student's ideological education work to large extent and guide the work. Take advantage of new media technology, counselors can spread the positive energy on campusin the process of education students. According to the new situation, update their own way of working and the method of education students. [7]

Thirdly, the Spirit of Craftsman Should Be Introduced Into the Construction of the Tutoring Studio to Integrate the Spirit of Craftsman.

Who the counselors faced with are the students that come from different ideological levels, quality level of students with partition, which is a great challenge to the counselors' psychological quality and the counselor's observation to grasp the student's individual situation. Situation is different, so students should be treated differently. They should try their best to find out students' thinking and action on all sorts of bad omen, then guide and direct their negative change. Constantly innovate the way we treat students and the education methods according to the changing times. Conduct the students' thought guidance and action guidance timely [8] Only be meticulous to every details can the work be done perfectly.

Since I am already in the position of the counselor, I will work hard and pay for the faith I have chosen, but I will try my best, and not expect anything in return. Being a craftsman like will surely let the spirit of craftsman leave a deep imprint in one's heart.

The perfect result requires constant suffering. Although the counselor's work is as heavy as a mountain, the work has become a daily routine for the counselors. If only a temporary excitement throughout your career, the burnout feeling will reassure the counselor work in a considerable degree of enthusiasm and sense of responsibility, and work quality will also be discounted. [9]

The counselor's job requires not only the perseverance of the ordinary hard work, but also the need to constantly encourage themselves to be full of enthusiasm and attitude. Only the members of the counselors' workshop are able to treat the upcoming work with full enthusiasm and fulfill their responsibilities so as to be perfect in their own beliefs. [10]

\section{Acknowledgements}

Funds of the Project: 2017 Jilin Province of "The 13th five-year" plan in Educational Science and the Major Subject " The Study of "Craftsman's Spirit under the view of the Construction of University Counsellor Studio"(ZD17019)

Author: Yunfeng Huang, male, the Student Work Office in the Foreign Language Department of Beihua University, Lecturer, mainly engaged in the study of the ideological education of the undergraduate ; Baosheng Guo, male, corresponding author, the Student Work Office of Beihua University, Associate professor, mainly engaged in the study of the ideological education of the undergraduate

\section{References}

[1] Z. Zhou. College Counselors Conduct Psychological Counseling and Path Research. Beijing Jiaotong University, 2011.(In Chinese)

[2] J.L. Li. A brief Analysis of the Development of the Basic Education in China's Urban and Rural Areas. Read fast (early), 2014. (In Chinese)

[3] Z.Q. Wang. Japanese Craftsman Spirit: Lifelong Focus on Doing Things [J]. China bicycle, 2016. (In Chinese) 
[4] F.D. Han. Chinese Craftsman Spirit, 2014. (In Chinese)

[5] H.M. Shi. Ethical Analysis and Countermeasure Research on the Professional Predicament of College Counselors [J]. Research on Ideological Politics Education, 2011. (In Chinese)

[6] The Modern Value of Craftsman Spirit [J]. Professional Education BBS, 2016. (In Chinese)

[7] X.D.Yu, J.W. Li, L.Y. Hu and K.T. Zhang. Qualitative Research on the Professionalization of Counselors [J]. Journal of Shandong Youth Management Cadre College, 2010. (In Chinese)

[8] W.J. Niu "CraftsmanSpirit" in the Journal of Academic Journals. Journal of Weinan Normal University, 2015. (In Chinese)

[9] J.X. Hu. A Study of Professional Standards of College Counselors [J]Research on Education, 2009. (In Chinese)

[10] Green Wood, Z.Li, Y.Q. Ding and L.M. Tu, German "Craftsman Spirit" how to Learn "Slow Work" not Impetuous [J]. Decision Exploration (second half), 2016. (In Chinese) 